\title{
Feasibility of cytological specimens for ALK fusion detection in patients with advanced NSCLC using the method of RT-PCR
}

\author{
Yan Wang ${ }^{\mathrm{a}}$, Yu Liu' ${ }^{\mathrm{c}}$, Chao Zhao ${ }^{\mathrm{b}}$, Xuefei Li ${ }^{\mathrm{b}}$, Chunyan $\mathrm{Wu}^{\mathrm{d}}$, Likun Hou ${ }^{\mathrm{d}}$, Shijia Zhang ${ }^{\mathrm{a}}$, \\ Tao Jiang ${ }^{\mathrm{a}}$, Xiaoxia Chen ${ }^{\mathrm{a}}$, Chunxia $\mathrm{Su}^{\mathrm{a}}$,Guanghui $\mathrm{Gao}^{\mathrm{a}}$, Wei $\mathrm{Li}^{\mathrm{a}}$, Fengying $\mathrm{Wu}^{\mathrm{a}}$, Aiwu \\ $\mathrm{Li}^{\mathrm{a}}$, Shengxiang Ren ${ }^{\mathrm{a}}$, Caicun Zhou ${ }^{\mathrm{a}}$, Jun Zhang ${ }^{\mathrm{e}}$ \\ a Department of Medical Oncology, Shanghai Pulmonary Hospital, Tongji University School of Medicine,
} Shanghai, P.R.China

${ }^{\mathrm{b}}$ Department of Lung Cancer and Immunology, Shanghai Pulmonary Hospital, Tongji University School of Medicine, Shanghai, P.R.China

${ }^{\mathrm{c}}$ Department of Radiotherapy, Shanghai Pulmonary Hospital, Tongji University School of Medicine, Shanghai, P.R.China

${ }^{\mathrm{d}}$ Department of Pathology, Shanghai Pulmonary Hospital, Tongji University School of Medicine, Shanghai, P.R.China

${ }^{\mathrm{e}}$ Division of Hematology, Oncology and Blood \& Marrow Transplantation, Department of Internal Medicine, Holden Comprehensive Cancer Center, University of Iowa Carver College of Medicine, Iowa City, Iowa.

The first 3 authors contribute equally to this manuscript

Corresponding author: Shengxiang Ren, MD, PhD, Department of Medical Oncology, Shanghai Pulmonary Hospital, Tongji University School of Medicine; Tongji University Medical School Cancer Institute. No. 507 Zheng Min Road, Shanghai, 200433, P.R. China; Fax: 086-21-55660346; harry_ren@126.com. 
Caicun Zhou, MD, PhD, Department of Medical Oncology, Shanghai Pulmonary Hospital, Tongji

University School of Medicine, Tongji University Medical School Cancer Institute, No. 507 Zheng Min

Road, Shanghai 200433, P.R. China, Fax:186-21-55660346, E-mail: caicunzhoudr@163.com. 


\begin{abstract}
Objectives: Histological tissues are preferred for anaplastic lymphoma kinase (ALK) fusion detection in non-small cell lung cancer (NSCLC). The aim of this study was to evaluate the feasibility of cytological sample as an alternative specimen for ALK fusion testing in patients with advanced NSCLC.
\end{abstract}

Materials and Methods: Advanced NSCLC patients with cytological specimens or tumor tissue who had their ALK fusion status detected by the method of reverse transcriptase polymerase chain reaction(RT-PCR) in Shanghai Pulmonary Hospital, Tongji University were included into this study. The efficacy was evaluated in those with ALK fusion positive and received the therapy of crizotinib.

Results: 1274 patients were included in this study. Among them, 108 patients were ALK RT-PCR positive and 69 of them received crizotinib treatment. Among 1002 patients with cytological specimens, the average concentration of RNA extracted from cytological specimens was $60.99 \mathrm{ng} / \mu \mathrm{l}(95 \%$ confidence interval[CI], 55.56-66.60) and the incidence rate of ALK fusion was $8.3 \%$ (83/1002), which were similar to $63.16 \mathrm{ng} / \mu \mathrm{l}(95 \% \mathrm{CI}$, $51.88-76.34)(\mathrm{p}=0.727)$ and $9.2 \%(25 / 272, \mathrm{p}=0.624)$ in 272 patients with tumor tissue. Also, there were no statistically significant differences regarding to the objective response rate $(\mathrm{ORR})(62.0 \% \mathrm{vs} .42 .1 \%, \mathrm{p}=0.177)$ and the median progression free survival (mPFS) [8.6 months (95\% CI 7.30-9.84) vs7.0 months (95\% CI 4.54-9.47), 
$\mathrm{p}=0.736]$ in patients of cytological group and tissue group after the treatment of crizotinib.

Conclusion: Cytological specimens showed a high feasibility to detect ALK fusion status, which could be regarded as alternative samples for ALK fusion detection by the method of RT-PCR in patients with advanced NSCLC.

Keywords: NSCLC; ALK; cytological specimens; RT-PCR; crizotinib 


\section{Introduction}

Precision medicine has come into reality for patients with advanced non small cell lung cancer(NSCLC) since epidermal growth factor receptor tyrosine kinase inhibitors (EGFR-TKIs) or anaplastic lymphoma kinase $(A L K)$ inhibitors has showed dramatic response in these with $E G F R$ mutation or $A L K$ fusion respectively ${ }^{[1-5]}$. Therefore, the detection of driver genes mutation status becomes essential to guide therapeutic decision in clinical practice.

As for $A L K$ fusion detection, several methods have been developed, including fluorescent in situ hybridization (FISH), immunohistochemistry(IHC) and reverse transcriptase polymerase chain reaction(RT-PCR). FISH is the first accompanied diagnostic assay approved by the FDA. Recently, Ventana IHC has also been approved by FDA since it showed a high consistency with FISH. However, both methods require relatively good quality specimen that contains sufficient cellular contents (e.g. nuclei number for FISH and protein level for IHC, etc.) for analysis. Therefore, histological tissue is preferred over cytological specimen. While, in clinical practice, patients with advanced stage NSCLC are unsuitable for radical surgery or biopsy. Thus, cytological samples were the major specimens to undergo molecular testing. For example, a survey from Asia showed that cytological samples were used to detect EGFR mutation status in as high as $50 \%$ of NSCLC patients ${ }^{[6]}$. Cell block could act as a complementary source of cytological 
specimens for FISH/IHC ${ }^{[7-10]}$, while not all cytological cell blocks can be made successfully. In Sanz-Santos et al's study, less than 50\% aspirates from endobronchial ultrasound-guided transbronchial needle aspiration (EBUS-TBNA )could be made into cell blocks and only $37.6 \%$ of them contained diagnostic material ${ }^{[11]}$.

RT-PCR, another alternative $A L K$ fusion diagnostic assay, is rapid and convenient to perform and can be readily applied to cytological specimens such as bronchial washing fluid or pleural effusion that may not be suitable to be prepared as paraffin-embedded blocks ${ }^{[12]}$. Our previous study together with Rosell's showed that the incidence of EML4-ALK fusion was higher when detected by RT-PCR compared to IHC or FISH analysis ${ }^{[13,14]}$. In this regard, the Chinese Food and Drug Administration has approved ADx EML4-ALK fusion gene diagnostic kit to be used to detect $A L K$ fusion, and this particular assay has also been accepted by Chinese Anti-Cancer Association ${ }^{[15-18]}$. However, up to now, it is still unknown whether we can use cytological specimen for RT-PCR to detect $A L K$ fusion and achieve comparable value in clinical decision. In addition, there is no data has ever addressed the best source and quality criteria of the cytological specimen for this RT-PCR approach.

Aim to evaluate the feasibility of cytological samples to detect $A L K$ fusion status with the method of RT-PCR, we compared RNA yields and the incidence of $A L K$ fusion between cytological specimens with tumor tissues in 1274 patients with advanced NSCLC. 
Moreover, we compared the efficacy of crizotinib in patients with $A L K$ fusion according to different types of specimen.

\section{Method}

\section{Patients}

Eligible Patients were those who had histologically confirmed stage IV NSCLC and had their $A L K$ fusion status detected by RT-PCR at Shanghai Pulmonary Hospital, Tongji University School of Medicine, Shanghai, China. Their clinical data were collected including age, gender, smoking status, Eastern Cooperative Oncology Group (ECOG) performance status (PS), and previous therapies. Nonsmokers were defined as patients who had smoked less than 100 cigarettes in their lifetime. Tumor response was evaluated 1 month after the initiation of crizotinib therapy ( $250 \mathrm{mg}$, twice daily) and then every 2 months afterward according to response evaluation criteria in solid tumors (version 1.1). Progression-free survival (PFS) was defined as the time interval from the first day of treatment to documented disease progression or death of any cause. Adverse events were assessed and classified according to national cancer institute common terminology criteria for adverse effects (CTCAE version 4.0). This study was approved by the ethics committee of Shanghai Pulmonary Hospital, Tongji University, Shanghai, China, and a written informed consent was obtained from each participant before the initiation of any study-related procedure. 


\section{Specimen preparation and RNA extraction}

For all cytology specimen obtained via FNA, one part was sent to the pathologists, whereas another part was immediately placed in an RNase-free Eppendorf tube containing $500 \mu 1$ of RNA later (Cat No.AM 7021, life technologies) and stored at $-20^{\circ}$ C. Once the specimen was confirmed by our pathologists to have tumor cells of more than 50, the RNA later preserved part will be taken out to extract mRNA. For sputum samples, at least 50 tumor cells were confirmed by liquid-based cytology test before it was preceded to mRNA extraction. For effusion specimen, $\sim 50$ to $1200 \mathrm{ml}$ of tumor containing effusion was centrifuged at 2,500 rpm for 3 minutes to achieve a cell pellet, which was then incubated with erythrocyte lysate for 10 minutes. This mixture was centrifuged again at $2500 \mathrm{rpm}$ for 3 minutes and the resultant cell pellet was re-suspended in normal saline solution before RNA extract. While tumor tissues were stored in the formalin-fixed, paraffin-embedded (FFPE) blocks until use. No less than 5 slides were collected for RNA extraction as mentioned above. Either RNeasy Mini Kit (Qiagen, Hilden, Germany) or AmoyDx RNA Kit (Amoy Diagnostics Co, Xiamen, China) was used to extract mRNA, which was subsequently quantitated by NanoDrop 2000 Spectrophotometer (Thermo Scientific, Waltham, USA).

\section{$A L K$ fusion Detection}


ALK fusion were detected AmoyDx EML4-ALK Fusion Gene Diagnostic Kit (Cat No. ADx-FF04, Amoy Diagnostics Co, Xiamen, China). In brief, the mRNA extracted from the previous step was reverse transcribed to cDNA at $42^{\circ} \mathrm{C}$, followed by $\mathrm{PCR}$ amplification. The PCR condition of the cDNA was an initial denaturation at $95^{\circ} \mathrm{C}$ for 5 minutes, followed by $95^{\circ} \mathrm{C}$ for 25 seconds, $64^{\circ} \mathrm{C}$ for 20 seconds, and $72^{\circ} \mathrm{C}$ for 20 seconds to ensure the specificity; and up to 31 cycles of $93^{\circ} \mathrm{C}$ for 25 seconds, $60^{\circ} \mathrm{C}$ for 35 seconds, $72^{\circ} \mathrm{C}$ for 20 seconds. PCR amplification of cDNA was performed using forward primers that correspond to exons of EML4 and the reverse primers that anneal to exons of $A L K$ to detect 21 known $E M L 4-A L K$ fusion transcript variants, which include: E6;A19, E6;A20, E6ins33;A20, E6;ins18A20, E13;A20, E13;ins69A20, E20;A20, E20;ins18A20, E14ins11;del49A20, E14;del14A20, E14;del38A20, E15del60;del71A20, E2;A20, E2;ins117A20, E3;ins53A20, E17;ins30A20, E17ins61;ins34A20, E17ins65; A20, E17;ins68A20, E17del58;ins39A20 and E18;A20.Here "E" denotes EML4 and "A" denotes $A L K$. The fluorescence signal released from the PCR products was used to determine the amplification cycles $(\mathrm{Ct})$ needed. Assay reactions requiring $\mathrm{Ct}$ values of $\leq 30$ cycles were considered positive for one of the $A L K$ fusion. The details can be referred to our previous studies ${ }^{[13,19-22]}$. To reduce the false positive, we sequenced the 21 known variants to confirm $A L K$ fusion for the first 20 patients and then every 3 patients with $A L K$ RT-PCR positive fusion.

\section{Statistical analysis}


All of the statistical tests were performed using the SPSS 19.0. Chi-square test or Fisher's exact test was used to examine the association between the $A L K$ fusions and the clinical factors and the response rate comparison. The Kaplan-Meier method was used to estimate the PFS and the log-rank test was used to analyze the PFS between the different groups. Results were considered significantly different if the $p$ value was less than 0.05 in a two-way analysis.

\section{Results}

\section{Patients' characteristics}

From October $1^{\text {st }} 2013$ to April $30^{\text {th }} 2015,1274$ patients entered into this study including $1002(79 \%)$ with cytological specimen and $272(21 \%)$ with tumor tissue. Their clinical characteristics were shown in Table 1 . Among the 1002 with cytological specimens, 746 were from needle aspiration, including 547 from CT-guided transthoracic needle aspiration(TTNA),86 from endobronchial ultrasound-guided transbronchial needle aspiration(EBUS-TBNA),107 from needle aspiration of superficial lymph nodes and 6 from needle aspiration of subcutaneous nodules, 254 were effusion samples, including 239 malignant pleural effusions(MPE), 12 pericardial effusions, 3 ascites and 2 were sputum samples. Figure1 shows the detail of specimen types. Among 272 patients with tumor tissue, 79 patients had paired cytological and tissue samples and were included as tissue group only in statistical analysis. 


\section{RNA concentrations}

The concentration of RNA was measured by spectrophotometry. The average RNA concentration of 1002 cytological specimens was $60.99 \mathrm{ng} / \mu 1$ ( $95 \%$ confidence interval[CI], 55.56-66.60), which was similar as $63.16 \mathrm{ng} / \mu \mathrm{l}(95 \% \mathrm{CI}, 51.88-76.34)$ $(\mathrm{p}=0.727)$ from 272 tissue(Figure2A).

RNA concentration were further analyzed according to different cytological specimen types. The average RNA concentration from 254 effusions was $78.95 \mathrm{ng} / \mu \mathrm{l}(95 \% \mathrm{CI}$, 64.07-93.83), which was significantly higher than $55.20 \mathrm{ng} / \mu \mathrm{l}(95 \% \mathrm{CI}$, 49.86-66.55) $(\mathrm{p}=0.010)$ from 746 needle aspiration samples. When needle aspiration samples were divided into TTNA, EBUS-TBNA and SLN-NA subgroups, the average RNA concentration had no statistically significant difference among them $(\mathrm{p}=0.168)$. Also, the average concentration from tissue did not showed statistically significant difference when comparing with TTNA(p=0.976), EBUS-TBNA(p=0.712), SLN-NA(p=0.125) and effusions $(\mathrm{p}=0.279)$ (Figure 2B).

The RNA concentration of specimens detected as $A L K$ positive ranged from $1.16 \mathrm{ng} / \mu \mathrm{l}$ to 462.14ng/ $\mu 1$ (Table2). The minimum case was extracted from a sample acquired from TTNA and the result had been confirmed by sequencing as EML4-ALK fusion type of variant $1(E 13 ; A 20)$. 


\section{$A L K$ fusion detection}

RT-PCR was performed for all 1274 patients, 108(8.5\%) of which were $A L K$ fusion positive. Among them, the incidence of $A L K$ fusion was $8.3 \%(83 / 1002)$ in patients with cytological specimens, which was similar as patients with tumor tissues $(25 / 272,9.2 \%, p=0.624) .50(50 / 108,46.3 \%)$ positive specimens were further confirmed by sequencing in which no false positive case was found and the results showed 25 cases in variant $1(E 13 ; A 20), 17$ in variant $3 \mathrm{a} / 3 \mathrm{~b}(E 6 ; A 20 / E 6$ ins $33 A 20), 6$ in variant2(E20;A20), 1 in variant $5(E 2 ; A 20)$ and 1 in variant 5' $(E 18 ; A 20)$.

As for 79 patients with paired cytological and tissue samples, we retrospectively randomly selected 5 samples with $A L K$ positive and 5 with $A L K$ negative detected by tumor tissue, and used their paired cytological specimens to compared the consistency of $A L K$ fusion status. The results showed there were $100 \%$ consistent (The details were in Supplementary Table 1). The 10 patients with paired samples were included into statistical analysis as tissue group only.

Subgroup analysis showed that $A L K$ positive was more frequently in younger $(<65$ years, $p=0.001)$, female $(p=0.003)$, non-smoker $(p<0.001)$ and adenocarcinoma $(p<0.001)$, while there were no statistically significant difference regarding to different ECOG PS and previous treatment (shown in Table 1). 


\section{The efficacy and side effect of crizotinib}

Totally, 69 of the 108 patients with $A L K$ RT-PCR positive received the treatment of crizotinib, including 50 with cytological specimens and 19 with tissue. Their baseline characteristics were not significantly different regarding to age ( $<65$ years, $\geq 65$ years), gender, smoking status, histology, ECOG PS and lines of previous treatment (Table 3). Among the 50 patients with cytological specimens, 2 patient had a complete response, 31 had a partial response and 8 got a stable disease. Thus, the objective response rate (ORR) and the disease control rate (DCR) were $62.0 \%$ and $78.0 \%$ respectively, which were similar to $42.1 \%(8 / 19, \mathrm{p}=0.177)$ and $84.2 \%(16 / 19, \mathrm{p}=0.742)$ in the 19 patients with tissue.

In all 69 patients received the therapy of crizotinib, 11 patients $(15.9 \%)$ were still on ALK-TKIs and 43(62.3\%) were still alive at the last follow-up of Jul $31^{\text {st }}, 2015$. The median overall survival (OS) still has not reached. mPFS was 8.6 months $(95 \% \mathrm{CI}$ $7.30-9.84)$ in patients with cytological specimens, which was similar as 7.0 months $(95 \%$ CI 4.54-9.47) $(\mathrm{p}=0.736)$ in patients with tissue (Figure3). The mPFS did not show statistically significant difference according to different age ( $<65$ years vs. $\geq 65$ years, 8.6 vs.10.2 months, $\mathrm{p}=0.797$ ), gender (male vs female, 8.4 vs.12.4 months, $\mathrm{p}=0.091$ ), smoking status (never vs. ever,8.6 vs.9.9 months, p=0.263),ECOG PS(0-1vs. $\geq 29.3$ vs. 
6.5 months, $\mathrm{p}=0.094)$ and lines of previous treatment(0-1 vs.2-4 9.9 vs 8.4 months, $\mathrm{p}=0.544)$.

The most frequent drug-related adverse effects during crizotinib therapy were visual disturbance $(43 \%)$, transaminitis $(38 \%)$, nausea(35\%). Patients experienced grade 3-4 events including 2 case with grade 4 transaminitis, 1 with grade 3 vomiting, and 1 with grade 3 esophagitis.

\section{Discussion}

As far as we know, this study was the first one to investigate the feasibility of $A L K$ fusion detection in a large scale of cytological samples with the method of RT-PCR. We compared the RNA yield in 1002 advanced NSCLC patients with cytological specimens with 272 with tumor tissue and found the average RNA concentration was $60.99 \mathrm{ng} / \mu \mathrm{l}$ in cytological sample, which was similar as $63.16 \mathrm{ng} / \mu \mathrm{l}(\mathrm{p}=0.727)$ in tumor tissue. Also, the incidence of $A L K$ fusion is similar ( $8.3 \%$ vs $9.2 \%, \mathrm{P}=0.624)$ in the both group. What's more, both groups showed a similar efficacy of crizotinib regarding to ORR and mPFS. Taken together, cytological specimens are feasible and should be recommended for $A L K$ fusion detection by RT-PCR in patients of advanced NSCLC.

The implementation of precision medicine depends on the acquisition of tumor cells for 
driver mutation analysis. A survey on EGFR mutation detection in Asia showed that patients with cytological samples contributed as high as $50 \%$ of the whole population who had undergone $E G F R$ mutation testing ${ }^{[6]}$, suggesting that cytological samples was the main source for molecular analysis in clinical practice. Our previous study also found that EBUS guided needle aspiration provide sufficient tumor cell for multiple biomarker testing such as EGFR mutation, ERCC1, RRM1 and BRCA1 mRNA expression ${ }^{[23]}$. However, comprehensive analysis cytological samples such as pleural effusions, fine needle biopsy and so on to perform $A L K$ fusion testing is still unknown. In this study, we found that cytological samples provides similar RNA yield as lung cancer tissues in patients with NSCLC (60.99 ng/ $\mu \mathrm{l}$ vs.63.16 ng/ $\mu 1, \mathrm{p}=0.727)$. Furthermore, we compared the RNA yields in cytological subgroups and found that it was higher in the malignant effusions than needle aspiration sample group, potential explanation might be that the cancer cells were collected by repeatedly centrifuged in amount of effusions. Moreover, we investigated the association of RNA concentration with $A L K$ fusion status and found that the minimum RNA concentration was $1.16 \mathrm{ng} / \mu \mathrm{l}$ in $A L K$ positive patient. This patient received a TTNA and the sequencing result showed EML4-ALK fusion type of E13;A20. He experienced partial response after the treatment of crizotinib with a PFS of 5.43 months, which indicated that RT-PCR is sensitive and has a low requirement for the cytological testing samples. 
Currently, FISH, Ventana IHC and RT-PCR are three approved and recommended methods for $A L K$ fusion detection. Among them, RT-PCR is free from subjective bias in analysis and can be readily applied to cytological specimens ${ }^{[12,24]}$. Several studies have demonstrated that there is a high concordance between the RT-PCR with FISH or IHC ${ }^{[13,14,25-29]}$. In our previous study, we compared RT-PCR with FISH to detect $A L K$ fusion in 255 patients and revealed a concordance rate of $99.2 \%{ }^{[13]}$. Thus, RT-PCR was selected as the $A L K$ fusion detection method in this study. We found the incidence of $A L K$ fusions was $8.3 \%$ (83/1002) in patients with cytological specimens, which was similar to patients with tumor tissue $(9.2 \%, 25 / 272, \mathrm{p}=0.624)$ and also was in the range of incidence that previous reported in the Asian NSCLC population ${ }^{[30-35]}$. The frequency seems to be higher than that in Caucasian population, part of the explanation was that a part of patients was selected as $E G F R$ wild population. Our previous study has shown that the frequency of $A L K$ fusion could be as high as $32.3 \%$ among selected patients who have never smoked and had adenocarcinoma harboring wild-type $E G F R^{[19]}$. The $A L K$ fusion were associated with a younger age, female, non-smoker and adenocarcinoma, which were consistent with previous studies ${ }^{[33,36,37]}$. As for efficacy evaluation, no significant differences were found regarding to both ORR (62.0\% vs.42.1\%, $\mathrm{p}=0.177)$ and mPFS[8.6 months (95\% CI 7.30-9.84) vs7.0 months (95\% CI 4.54-9.47), $\mathrm{p}=0.736]$ after the crizotinib treatment in cytological group and tissue group. The mPFS in the whole population was 8.4 months (95\% CI 6.41-10.39), which was fell in the range of 7.7 to 10.9 months as shown in the relevant phase I to III clinical trials ${ }^{[5,38,39]}$. 
As the first large-scale study, our study has several limitations. Firstly, this was a retrospective study with selected groups of patients, which could have inevitably induced a selection bias. For example, there were more patients with adenocarcinoma and some already had known wild type EGFR. Secondary, the lack of a comparison with cell block and further validation by other detection methods, such as FISH and IHC made our less convictive. On the other hand, the observational nature of this study made our results more reproduceable in the real-world. Thirdly, although we had a large population of patients with cytological sample ( $\mathrm{n}=1002$ patients), the sputum and subcutaneous nodules samples were relatively small. Thus, the finding of this article could not be generalized into these subpopulations.

In conclusion, our results showed that cytological specimens had a high feasibility to perform $A L K$ fusion status detection by RT-PCR, which might be regarded as feasible sample source for $A L K$ detection in patients of advanced NSCLC.

\section{Acknowledgments}


This study was supported in part by grants from the National Science Foundation of China (No. 81201707), projects of the Science and Technology Commission of Shanghai Municipality (No. 12ZR1426000), key project of Shanghai Municipal Com-mission of

Health and Family Planning (No. 2013zyjb0401) and Outstanding Young Doctor Program of Shanghai Municipal Commission of Health and Family Planning (No. XYQ2013097).

\section{Reference}

1. Mok TS, Wu YL, Thongprasert S, et al. Gefitinib or carboplatin-paclitaxel in pulmonary adenocarcinoma. N Engl J Med 2009;361:947-957.

2. Rosell R, Gervais R, Vergnenegre A, et al. Erlotinib versus chemotherapyin advanced non-small cell lung cancer (NSCLC) patients with epidermal growth factor receptor (EGFR) mutations: Interim results of the European erlotinib versus chemotherapy (EURTAC) phase III randomized trial. J Clin Oncol 2011;29:7503.

3. Zhou $\mathrm{C}, \mathrm{Wu} \mathrm{YL}, \mathrm{Chen} \mathrm{G}$, et al. Erlotinib versus chemotherapy as first-line treatment for patients with advanced EGFR mutation-positive non-small cell lung cancer (OPTIMAL, CTONG-0802): a multicentre, open-label,randomised, phase 3 study. Lancet Oncol 2011;12:735-742

4. Kwak EL, Bang YJ, Camidge DR, et al. Anaplastic lymphoma kinase inhibition in non-small-cell lung cancer. N Engl J Med 2010;363:1693-1703 
5. Solomon BJ, Mok T, Kim DW,et al; PROFILE 1014 Investigators. Firstline crizotinib versus chemotherapy in ALK-positive lung cancer. $\mathrm{N}$ Engl $\mathrm{J}$ Med $2014 ; 371: 2167-2177$

6. Yatabe Y, Kerr KM, Utomo A,et al,EGFR mutation testing practices within the Asia Pacific region: results of a multicenter diagnostic survey.J Thorac Oncol. 2015 Mar;10(3):438-45

7. Zanini C, Forni M. The cell block technique revisited for cells cultured in adherence and as“"spheres”. Histochem Cell Biol 2013;140:685-690

8. Zhou J, Yao H, Zhao J,et al.Cell block from malignant pleural effusion might be a valid alternative sample for ALK detection in patients with advanced non small cell lung cancer.Histopathology. 2015 Jun;66(7):949-54.

9. Liu L, Zhan P, Zhou X, et al. Detection of EML4-ALK in Lung Adenocarcinoma Using Pleural Effusion with FISH,IHC, and RT-PCR Methods. PLoS ONE 2015;10(3):e0117032.

10. Wang W, Tang Y, Li J, Jiang L, Jiang Y, Su X.Detection of ALK rearrangements in malignant pleural effusion cell blocks from patients with advanced non-small cell lung cancer: a comparison of Ventana immunohistochemistry and fluorescence in situ hybridization.Cancer Cytopathol. 2015 Feb;123(2):117-22.

11. Sanz-Santos J, Serra P, Andreo F, Llatjos M, Castella E, and Monso E.Contribution of cell blocks obtained through endobronchial ultrasound-guided transbronchial needle aspiration to the diagnosis of lung cancer. BMC cancer 2012;12, 34 . 
12. Soda $\mathrm{M}$, Isobe $\mathrm{K}$, Inoue $\mathrm{A}$, et al. A prospective PCR-based screening for the EML4-ALK oncogene in non-small cell lung cancer. Clin Cancer Res $2012 ; 18: 5682-5689$

13. Wang Y, Zhang J,Gao G,et al.EML4-ALK fusion detected by RT-PCR confers similar response to crizotinib as detected by FISH in patients with advanced NSCLC.J Thorac Oncol.2015;10:1546-1552.

14. Teixidó C, Karachaliou N, Rosell R, et al. Concordance of IHC, FISH and RT-PCR for EML4-ALK rearrangements. Transl Lung Cancer Res 2014;3:70-74.

15. Prospective product list issued on March 22,2013[China Food and Drug AdministrationWebSite].Availableat:http://www.sda.gov.cn/WS01/CL0403/79275.ht ml.Accessed March 22,2013.

16. Shi YK, Liu TH, Sun Y, et al. Guideline for diagnosis and treatment of non-small cell lung cancer patients with epidermal growth factor receptor mutation or anaplastic lymphoma kinase rearrangement(2013): oncology branch of Chinese Medical Doctor Association Chemotherapy Committee of Chinese Anti-cancer Association. Chin J Oncol 2013;35:478-479.

17. Zhang $\mathrm{X}, \mathrm{Lu} \mathrm{S}, \mathrm{Wu}$ YL, et al. The diagnostic of anaplastic lymphoma kinase (ALK) positive non-small cell lung cancer: Chinese expert consensus(2013). Chin J Pathol $2013 ; 42: 402-406$. 
18. Wu G, Zhou C, Bai C, et al. Chinese expert consensus on molecularly targeted therapy for advanced non-small cell lung cancer (2013 edition).J Thorac Dis $2014 ; 6: 1489-98$

19. Ren S, Kuang P, Zheng L, et al. Analysis of driver mutations in female non-smoker Asian patients with pulmonary adenocarcinoma. Cell Biochem Biophys 2012;64:155-160.

20. Ren S, Chen X, Kuang P, et al. Association of EGFR mutation or ALK rearrangement with expression of DNA repair and synthesis genes in never-smoker women with pulmonary adenocarcinoma. Cancer 2012;118:5588-5594.

21. Zhao C, Li X, Li J, et al. Detecting ALK, ROS1 and RET fusion genes in cell block samples. Translational Oncol 2014;7:363-367.

22. Wu C, Zhao C, Yang Y, et al. High discrepancy of driver mutations in patients with NSCLC and synchronous multiple lung ground-glass nodules.J Thorac Oncol 2015;10:778-783.

23. Schmid-Bindert G, Wang Y, Jiang H,et al. EBUS-TBNA Provides Highest RNA Yield for Multiple Biomarker Testing from Routinely Obtained Small Biopsies in Non-Small Cell Lung Cancer Patients - A Comparative Study of Three Different Minimal Invasive Sampling Methods. PLoS ONE 2013;8(10):e77948.

24. Takeuchi K, Choi YL, Soda M, et al. Multiplex reverse transcription-PCR screening for EML4-ALK fusion transcripts. Clin Cancer Res 2008;14:6618-6624. 
25. Gruber K, Horn H, Kalla J, et al. Detection of rearrangements and transcriptional up-regulation of ALK in FFPE lung cancer specimens using a novel, sensitive, quantitative reverse transcription polymerase chain reaction assay. $\mathrm{J}$ Thorac Oncol 2014;9:307-315.

26. Demidova I, Barinov A, Savelov N, et al. Immunohistochemistry, fluorescence in situ hybridization, and reverse transcription-polymerase chain reaction for the detection of anaplastic lymphoma kinase gene rearrangements in patients with non-small cell lung cancer: potential advantages and methodologic pitfalls. Arch Pathol Lab Med 2014;138:794-802.

27. Moskalev EA, Frohnauer J, Merkelbach-Bruse S, et al. Sensitive and specific detection of EML4-ALK rearrangements in non-small cell lung cancer (NSCLC) specimens by multiplex amplicon RNA massive parallel sequencing. Lung Cancer 2014;84:215-221.

28. Wang J, Cai Y, Dong Y, et al. Clinical characteristics and outcomes of patients with primary lung adenocarcinoma harboring ALK rearrangements detected by FISH, IHC, and RT-PCR. PLoS One 2014;9:e101551.

29. Shan L, Lian F, Guo L, et al. Combination of conventional immunohistochemistry and qRT-PCR to detect ALK rearrangement. Diagn Pathol 2014;9:3.

30. Sun Y, Ren Y, Fang Z, et al. Lung adenocarcinoma from East Asian neversmokers is a disease largely defined by targetable oncogenic mutant kinases. J Clin Oncol 2010;28:4616-4620. 
31. An SJ, Chen $\mathrm{ZH}, \mathrm{Su}$ J, et al. Identification of enriched driver gene alterations in subgroups of non-small cell lung cancer patients based on histology and smoking status. PLoS One 2012;7:e40109.

32. Xia N, An J, Jiang QQ, et al. Analysis of EGFR, EML4-ALK, KRAS, and c-MET mutations in Chinese lung adenocarcinoma patients. Exp Lung Res 2013;39:328-335

33. Wang J, Dong Y, Cai Y, et al. Clinicopathologic characteristics of ALK rearrangements in primary lung adenocarcinoma with identified EGFR and KRAS status. J Cancer Res Clin Oncol 2014;140:453-460.

34. Li C, Fang R, Sun Y, et al. Spectrum of oncogenic driver mutations in lung adenocarcinomas from East Asian never smokers. PLoS One 2011;6:e28204.

35. Pan Y, Zhang Y, Li Y, et al. ALK, ROS1 and RET fusions in 1139 lung adenocarcinomas: a comprehensive study of common and fusion patternspecific clinicopathologic, histologic and cytologic features. Lung Cancer 2014;84:121-126.

36. Shaw AT, Yeap BY, Mino-Kenudson M, et al.Clinical features and outcome of patients with non-small-cell lung cancer who harbor EML4-ALK. J Clin Oncol 2009;27: 4247-4253

37. Koh Y, Kim DW, Kim TM, et al. Clinicopathologic characteristics and outcomes of patients with anaplastic lymphoma kinasepositive advanced pulmonary adenocarcinoma: suggestion for an effective screening strategy for these tumors. J Thorac Oncol 2011;6: 905-912. 
38. Camidge DR, Bang YJ, Kwak EL,et al. Activity and safety of crizotinib in patients with ALK-positive non-small-cell lung cancer: updated results from a phase 1 study. Lancet Oncol 2012;13:1011-1019

39. Shaw AT, Kim DW, Nakagawa K, et al. Crizotinib versus chemotherapy in advanced ALK-positive lung cancer. N Engl J Med 2013;368:2385-2394. 


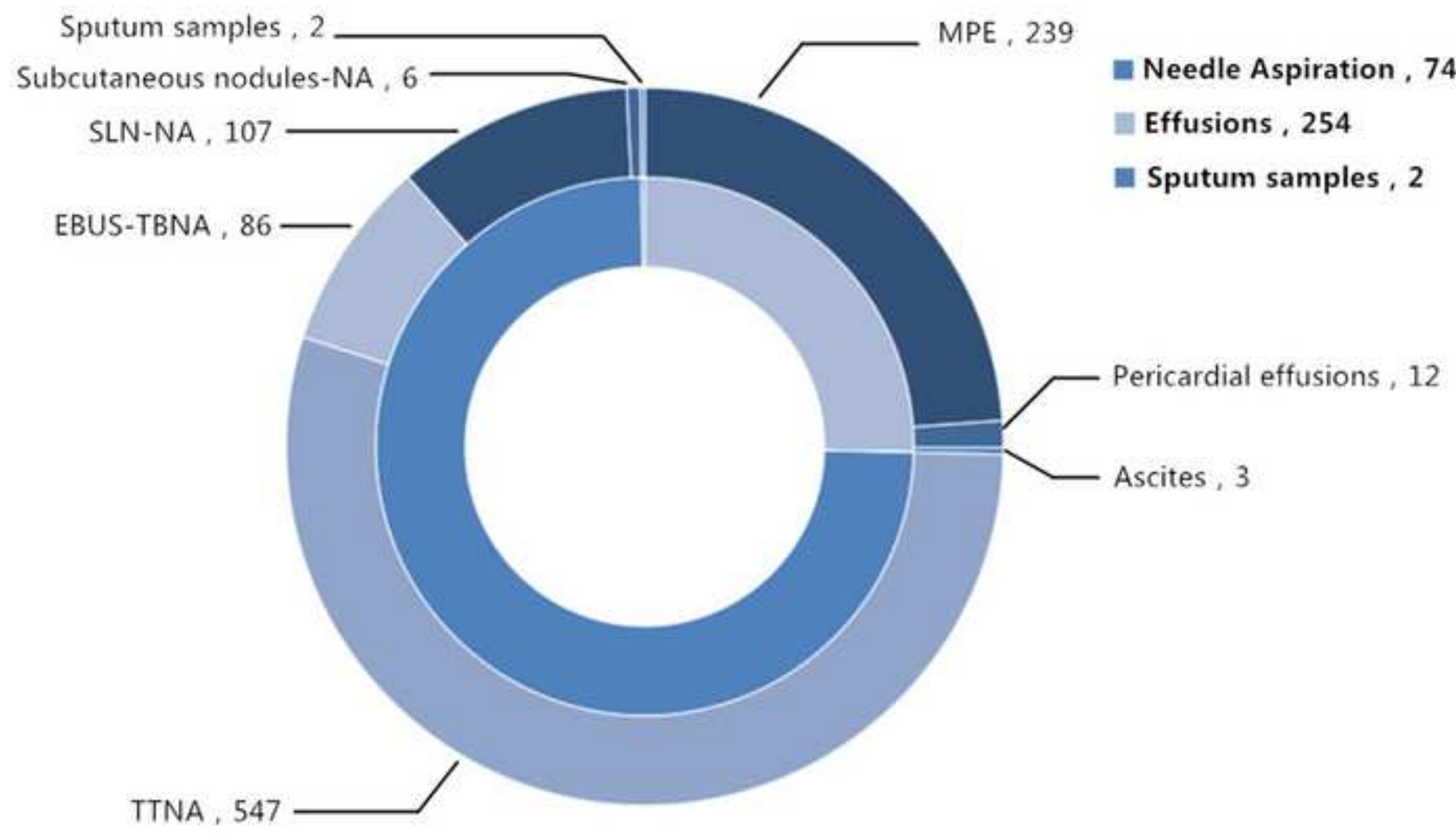


A

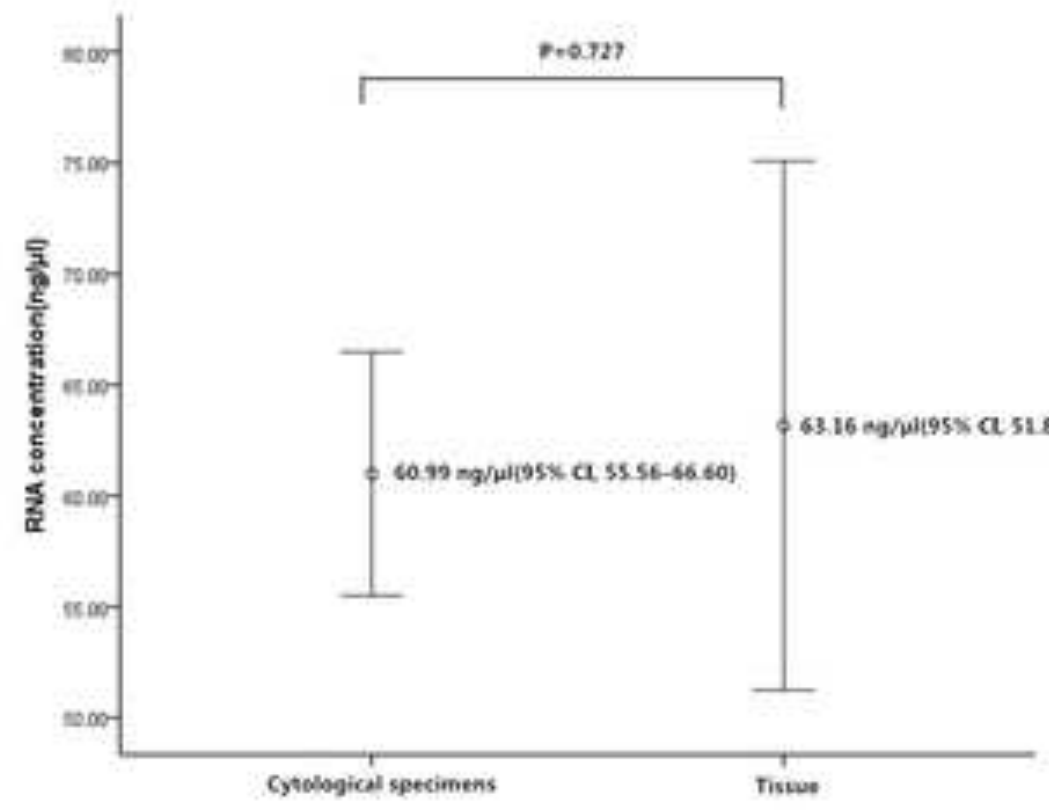

B

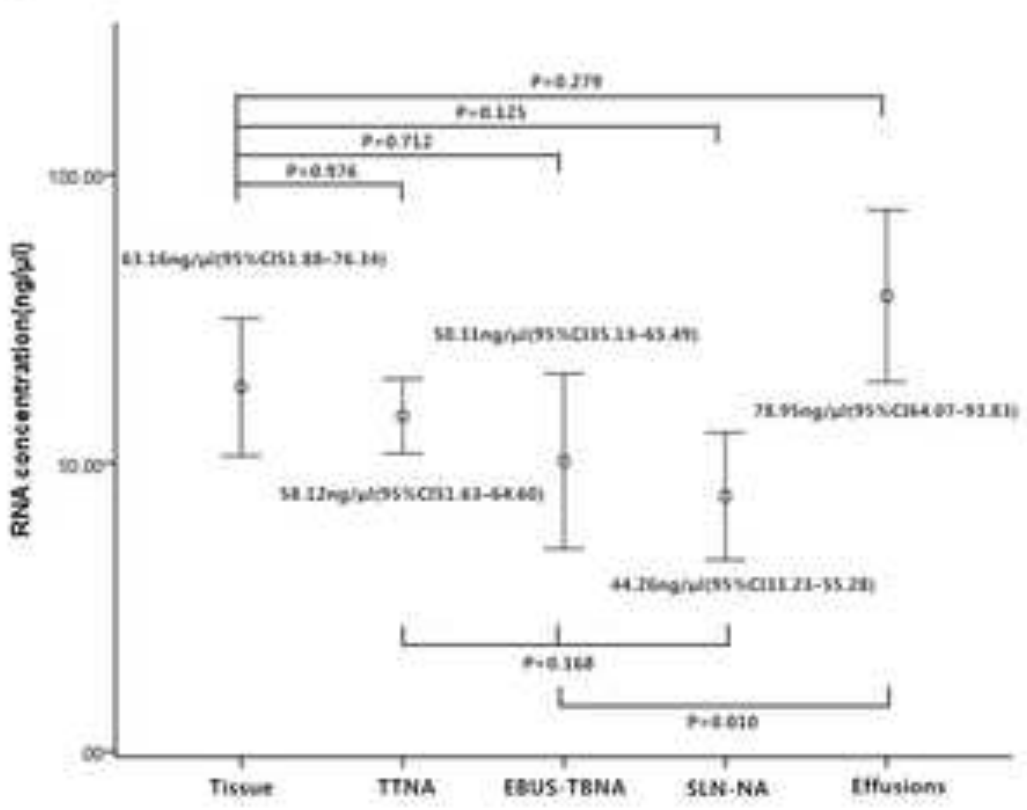




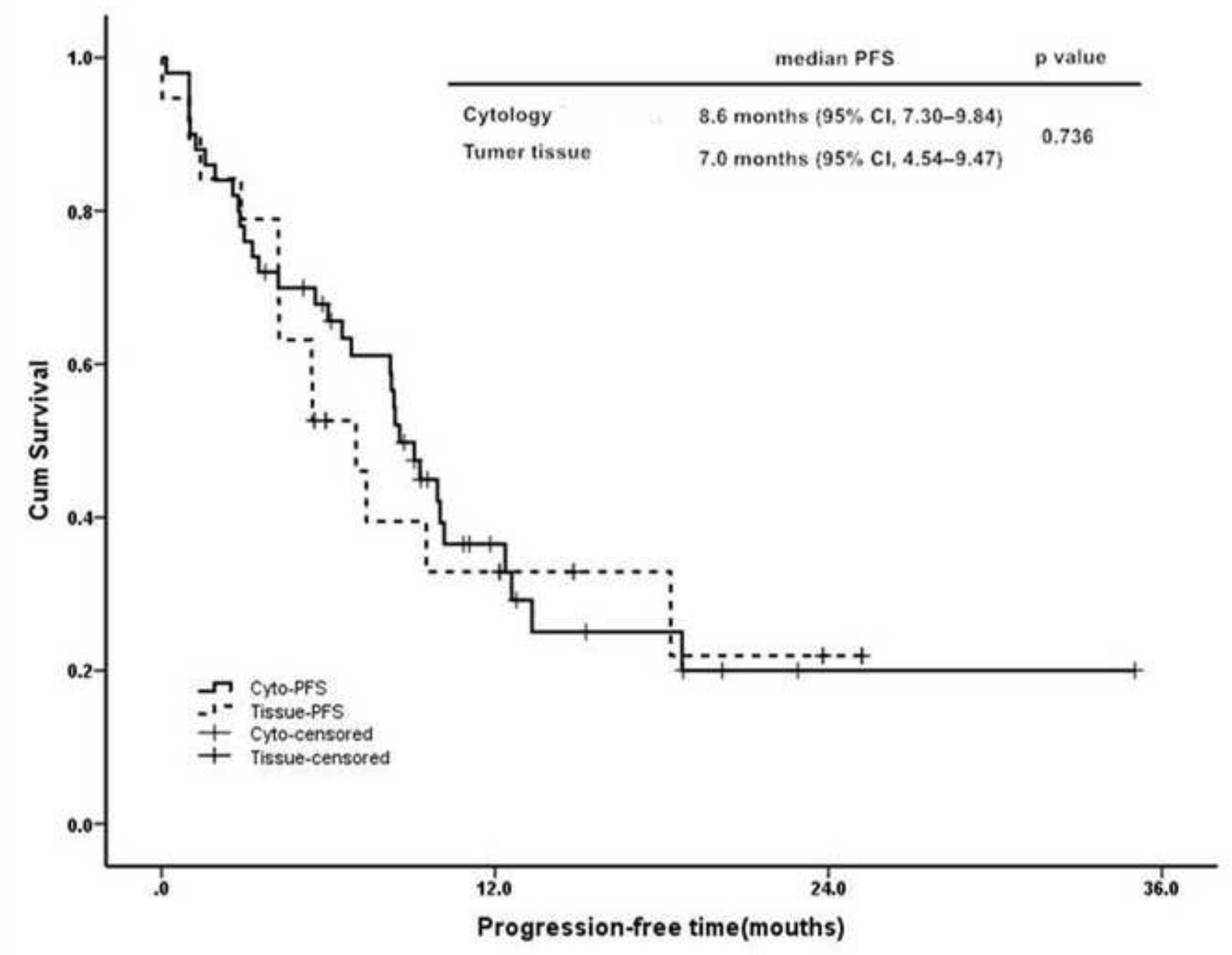


Figure captions

Figure 1 The type of specimens acquisition

TTNA $=\mathrm{CT}$-guided transthoracic needle aspiration,EBUS-TBNA=endobronchial ultrasound-guided transbronchial needle aspiration,SLN-NA=needle aspiration of superficial lymph nodes,subcutaneous nodules-NA=needle aspiration of subcutaneous nodules, and MPE=malignant pleural effusions.

Figure2 Comparison of average concentrations of RNA of different subgroup of samples.

Figure3 Comparison of the progression-free survival (PFS) curve 


\begin{tabular}{|c|c|c|c|c|}
\hline Clinical characteristics & $\begin{array}{c}\text { Total } \\
(n=1274)\end{array}$ & $\begin{array}{c}A \boldsymbol{L} K \text { negative } \\
(\mathrm{n}=1166)\end{array}$ & $\begin{array}{c}\boldsymbol{A} \boldsymbol{L} \boldsymbol{K} \text { positive } \\
(\mathrm{n}=108)\end{array}$ & P value * \\
\hline \multicolumn{5}{|l|}{ Age (years) } \\
\hline$<65$ & $792(62 \%)$ & $709(61 \%)$ & $83(77 \%)$ & 0.001 \\
\hline$\geq 65$ & $482(38 \%)$ & $457(39 \%)$ & $25(23 \%)$ & \\
\hline \multicolumn{5}{|l|}{ Gender } \\
\hline Male & $796(62 \%)$ & $743(64 \%)$ & $53(36 \%)$ & 0.003 \\
\hline Female & $478(38 \%)$ & $423(49 \%)$ & $55(51 \%)$ & \\
\hline \multicolumn{5}{|l|}{ Smoking status } \\
\hline Non-smoker & $567(45 \%)$ & $488(42 \%)$ & $79(73 \%)$ & $<0.001$ \\
\hline Smoker & $707(55 \%)$ & $678(58 \%)$ & $29(27 \%)$ & \\
\hline \multicolumn{5}{|l|}{ Histology } \\
\hline Adenocarcinoma & $998(78 \%)$ & $892(76 \%)$ & $106(98 \%)$ & $<0.001$ \\
\hline Squamous carcinoma & $271(21 \%)$ & $270(23 \%)$ & $1(<1 \%)$ & \\
\hline Adenosquamous carcinoma & $3(<1 \%)$ & $3(<1 \%)$ & $0(<1 \%)$ & \\
\hline Large cell carcinoma & $2(<1 \%)$ & $1(<1 \%)$ & $1(<1 \%)$ & \\
\hline \multicolumn{5}{|l|}{ ECOG PS score } \\
\hline $0-1$ & $978(77 \%)$ & $898(77 \%)$ & $80(74 \%)$ & 0.477 \\
\hline$\geq 2$ & $296(23 \%)$ & $268(23 \%)$ & $28(26 \%)$ & \\
\hline \multicolumn{5}{|c|}{ No. of previous chemotherapy } \\
\hline $0-1$ & $786(62 \%)$ & $723(62 \%)$ & $63(58 \%)$ & 0.470 \\
\hline $2-4$ & $488(38 \%)$ & $443(38 \%)$ & $45(42 \%)$ & \\
\hline \multicolumn{5}{|l|}{ Specimen type } \\
\hline Cytological specimens & $1002(79 \%)$ & $919(77 \%)$ & $83(79 \%)$ & 0.624 \\
\hline Tissue & $272(21 \%)$ & $247(23 \%)$ & $25(21 \%)$ & \\
\hline
\end{tabular}

Table1. The clinical characteristics of patients.

*The $\mathrm{p}$ value was used to compare the clinical characteristics between $A L K$ fusion positive and negative patients. 


\begin{tabular}{|c|c|c|c|c|c|c|}
\hline \multirow{2}{*}{ Sample Type } & \multicolumn{2}{|r|}{ Total $(n=1274)$} & \multicolumn{2}{|c|}{$A L K$ negative $(\mathrm{n}=1166)$} & \multicolumn{2}{|c|}{$A L K$ positive $(\mathrm{n}=108)$} \\
\hline & $\mathbf{n}$ & RNA yield* & $\mathbf{n}$ & RNA yield* & $\mathbf{n}$ & RNA yield* \\
\hline Tissue & 272 & $63.16(0.14-786.62)$ & 247 & $60.44(0.14-786.62)$ & 25 & $90.00(2.31-462.40)$ \\
\hline Cytological samples & 1002 & $60.99(0.09-894.50)$ & 919 & $62.24(0.09-894.50)$ & 83 & $47.12(1.16-462.14)$ \\
\hline From TTNA & 547 & $58.12(0.38-509.66)$ & 503 & $61.56(0.38-509.66)$ & 42 & $19.70(1.16-225.87)$ \\
\hline From EBUS-TBNA & 86 & $50.31(0.09-485.54)$ & 77 & $53.48(0.09-485.54)$ & 9 & $23.22(5.64-57.54)$ \\
\hline From SLN-NA & 107 & $44.26(1.02-401.20)$ & 98 & $45.41(1.02-401.20)$ & 9 & $31.79(4.42-64.66)$ \\
\hline $\begin{array}{l}\text { From subcutaneous } \\
\text { nodules-NA }\end{array}$ & 6 & $30.41(8.32-89.60)$ & 5 & $33.05(8.32-89.60)$ & 1 & $17.21(17.21-17.21)$ \\
\hline Sputum samples & 2 & $10.77(5.12-16.41)$ & 2 & $10.77(5.12-16.41)$ & $\mathbf{0}$ & \\
\hline MPE & 239 & $65.30(0.60-894.50)$ & 219 & $60.10(0.60-894.50)$ & 20 & $122.20(28.69-462.14)$ \\
\hline Pericardial effusions & 12 & $78.16(12.28-296.06)$ & 10 & 81.07(12.28-296.06) & 2 & $63.62(47.53-79.71)$ \\
\hline Ascites & 3 & $97.47(42.43-151.11)$ & 3 & $97.47(42.43-151.11)$ & $\mathbf{0}$ & \\
\hline
\end{tabular}

Table 2.The RNA yield in the different subgroup of samples

*Data are Average concentration(Minimum-Maximum)(ng/ $\mu \mathrm{l})$.

TTNA $=$ CT-guided transthoracic needle aspiration,EBUS-TBNA=endobronchial ultrasound-guided transbronchial needle aspiration,SLN-NA=needle aspiration of superficial lymph nodes, subcutaneous nodules-NA=needle aspiration of subcutaneous nodules, and MPE=malignant pleural effusions. 


\begin{tabular}{|c|c|c|c|}
\hline Clinical characteristics & $\begin{array}{l}\text { Cytological } \\
\text { specimens } \\
(n=50)\end{array}$ & $\begin{array}{c}\text { Tissue } \\
\text { specimens } \\
(n=19)\end{array}$ & P value \\
\hline \multicolumn{4}{|l|}{ Age (years) } \\
\hline$<65$ & $47(94 \%)$ & $16(84 \%)$ & 0.336 \\
\hline$\geq 65$ & $3(6 \%)$ & $3(16 \%)$ & \\
\hline \multicolumn{4}{|l|}{ Gender } \\
\hline Male & $29(58 \%)$ & $10(53 \%)$ & 0.788 \\
\hline Female & $21(42 \%)$ & $9(47 \%)$ & \\
\hline \multicolumn{4}{|l|}{ Smoking status } \\
\hline Non-smoker & $41(82 \%)$ & $14(74 \%)$ & 0.508 \\
\hline Smoker & $9(18 \%)$ & $5(26 \%)$ & \\
\hline \multicolumn{4}{|l|}{ Histology } \\
\hline Adenocarcinoma & $50(100 \%)$ & $18(95 \%)$ & 0.275 \\
\hline Non-adenocarcinoma & $0(0 \%)$ & $1(5 \%)$ & \\
\hline \multicolumn{4}{|l|}{ ECOG PS score } \\
\hline $0-1$ & $36(72 \%)$ & $13(68 \%)$ & 0.774 \\
\hline$\geq 2$ & $14(28 \%)$ & $6(32 \%)$ & \\
\hline \multicolumn{4}{|l|}{ No. of previous chemotherapy } \\
\hline $0-1$ & $29(58 \%)$ & $11(58 \%)$ & 1.000 \\
\hline $2-4$ & $21(42 \%)$ & $8(42 \%)$ & \\
\hline
\end{tabular}

Table3. The clinical characteristics of patients treated with crizotinib. 